\title{
Comparing dividend puzzle solutions by Polish, Canadian, Norwegian and American executives
}

\author{
Agata Sierpińska-Sawicz'
}

\begin{abstract}
This study compares firms' dividend policy antecedents in four countries. The author surveys managers of 230 companies listed on the Warsaw Stock Exchange that paid dividends over the 2001-12 period and compares the findings to survey reports from the USA, Canada, and Norway. The main antecedents of dividend policy in these countries are the level of current earnings, their stability over time, the level of expected earnings and the pattern of past dividends. The last factor is of little importance for Polish managers, as the history of dividend payouts in Polish-listed companies is brief. The establishment of factors that shape the dividend policy in public companies has crucial importance in global financial markets. Investors make cash transfers to markets that ensure a high return on invested capital. Orders from foreign investors generate almost 50\% of the turnover on the Warsaw Stock Exchange. Therefore, in their decisions on the division of earnings, Polish companies should be guided by similar considerations as those displayed by companies in developed economies that seek to attract foreign investors. The study expands on the existing survey research on dividends and provides new evidence from managers of companies in Poland.
\end{abstract}

KEY WORDS: $\quad$ dividend, survey, dividend policy, dividend antecedents, dividend determinants

JEL Classification: $\quad$ G35

${ }^{1}$ Poznan University of Economics, Poland

\section{Introduction}

Dividend policy plays a key role in the distribution of listed companies' net profits, but despite the existence of numerous studies, Brealey, Myers, Allen and Mohanty (2011) list dividends as one of the ten unresolved problems in contemporary corporate finance. The problem of decision-making with regard to dividend payments,

-

Correspondence concerning this article should be addressed to: Agata Sierpińska-Sawicz, Poznan University of Economics, Department of Controlling, Financial Analysis and Valuation, al. Niepodleglosci 10, 61-875 Poznań, Poland, E-mail: agata.sierpinska-sawicz@ue.poznan.pl described in the literature as the "dividend puzzle" (Black, 1976; Baker, Powell, \& Veit, 2002), emphasizes the role of three forces that influence dividend policy: managers, shareholders, and potential investors. Baker, Singleton and Veit (2011) assume that a major reason for this ongoing debate is the heavy reliance on economic modeling approaches and the lack of an in-depth understanding of how investors and managers behave and perceive dividends. Dividend policy continues to attract attention due to its linkage with corporate financing and investing decisions and its impact on shareholder wealth (Baker \& Jabbouri, 2016).

The Polish capital market is a unique case in the study of corporate dividends. Since the start of the reg- 
ulated stock exchange market, the State Treasury has privatized large factories by placing them on the stock exchange, the proceeds from which served to replenish the state budget. However, the Treasury continues to be the majority shareholder in strategic companies in the fuels, energy and mining sectors. Faced with a budget deficit, the Treasury expects to receive dividends from the companies in which it has a stake. Hence, these companies are the main dividend payers in the Polish market (Sierpińska-Sawicz, 2014).

In studying dividend policy, researchers typically rely on two main approaches: managerial surveys and statistical analyses of published financial data. Survey research complements research based on secondary data and provides additional insights into why firms make certain dividend policy decisions (Baker \& Weigand, 2015). Data on Polish companies listed on the regulated market are distorted by high inflation and interest rates, especially in the early years of privatization. Therefore, these data are difficult to apply in comparisons with long-term data from highly developed markets. In addition, compared with exchanges in mature economies, the Warsaw Stock Exchange (WSE) is in its early stages of development. Thus, the study presented in this paper relies on the questionnaire method. To provide further insight into how dividends are perceived from a managerial perspective in Poland, the present study surveys managers of dividend-paying firms listed on the WSE.

This study's analysis of the existing literature justifies the proposal of the following hypotheses. H1: The key antecedents of dividend policy in Poland relate to the level of the company's earnings, similar to the impact of earnings in the USA, Canada, and Norway. H2: The antecedents of dividend policy in Poland do not fundamentally differ from those in the USA, Canada, and Norway. Testing these hypotheses is important for the WSE. Almost 50\% of the turnover on the WSE stems from orders by foreign investors. Therefore, in their decisions on the division of earnings, Polish companies should be guided by similar considerations as those displayed by companies in developed economies that seek to attract foreign investors.

This research may be most comprehensive study that analyzes Polish managers' assessment of dividends. Subsequently, the outcomes are compared with survey research conducted in the USA, Canada and
Norway. The paper contributes to the dividend literature by expanding on the existing survey research on dividends and by providing new evidence from managers of companies in Poland.

\section{Literature review}

Lintner (1956) is the first to initiate manager surveys applied to dividend policy studies. His seminal research on US executives reports that the basic premises for dividend payments are the pattern of past dividends and the current level of earnings. Baker and Powell (2000) conduct surveys of CFOs of listed companies on the New York Stock Exchange (NYSE) from three industrial sectors: manufacturing, wholesale/retail groups and utilities. Their findings show that the most important factors influencing dividend payouts are the expected level of future earnings, the pattern of past dividends, the availability of cash and the desire to maintain or increase the share price. The same factors influence managers' dividend decisions for companies listed on the NASDAQ (Baker, Veit, \& Powell, 2001).

Baker, Saadi, Dutta, and Gandhi (2007) analyze managers' perceptions of dividends on the Toronto Stock Exchange (TSX). Their findings show that in Canada, the most important factors are the level of current and future earnings, their stability over time and the pattern of past dividends. This tendency holds among financial versus non-financial managers with reference to the four most important antecedents; however, there is an industry effect if the entire ranking is considered (Baker, Saadi, \& Dutta, 2008). Lintner (1956) reports that an industry effect may influence firms' corporate dividend policy and investor perceptions of dividends for firms in different industries. For example, firms operating in saturated and mature industries have a higher propensity to pay dividends than do firms in high-growth industries. Based on research in the USA, Canada, the UK, Germany, France and Japan, Denis and Osobov (2008), conclude that the propensity to pay dividends is connected to firms' size, growth opportunities and profitability and is higher among larger, more profitable firms.

Baker, Mukherjee, and Paskelian (2006) explore the perceptions of dividends among Norwegian managers. On the Oslo Stock Exchange (OSE), the most important antecedents other than those connected to earnings include the current degree of financial 

Table 1. Structure of the respondents by position

\begin{tabular}{lcc}
\hline Category of response & No. of responses & Structure, \% \\
\hline Chairperson & 18 & 21.4 \\
CFO & 26 & 31.0 \\
Another board member & 8 & 9.5 \\
Supervisory Board of Audit Committee member & 5 & 6.0 \\
Investor Relations Department & 27 & 32.1 \\
Total & 84 & 100.0 \\
\hline
\end{tabular}

Notes: Adapted from author's own calculations based on the WSE survey results.

In the second stage of the study, the author sent out a paper version of the survey and contacted the companies by telephone to ask them to complete the survey. In addition, the data collection procedure included an offer to send the companies the aggregate survey results so the companies could compare their own dividend policy with the results for the rest of the industry. As a result, over a three-month span, an additional 48 surveys were received, which resulted in a total of 84 complete questionnaires and a total response rate of $36.6 \%$. In line with the pertinent literature, this sample is deemed sufficient to verify the research hypotheses. For example, some studies feature the following response return rates: $32.9 \%$ for the NYSE (Baker, Powell, 2000), 29.8\% for the NASDAQ (Baker et al., 2001), 27.3\% for the Oslo Stock Exchange (OSE) (Baker et al., 2005) and $35.4 \%$ for the TSX (Baker et al., 2007).

Considering the characteristics of the respondents in terms of value, the market capitalization of the domestic respondents ( 82 out of 84 responses) accounts for $71 \%$ of the total capitalization of domestic companies listed on the WSE. With foreign companies included ( 2 out of 84 responses), respondents' capitalization amounts to nearly $50 \%$ of the WSE's total market capitalization at the end of 2012 (WSE data). Hence, nearly all the major dividend payers from the study period returned completed surveys. These are large companies with established market positions. A comparison of the antecedents of the dividend policy pursued by the WSE-listed companies with those of companies listed on the OSE, NYSE, NASDAQ and TSX is justified because, as Denis and Osobov (2008) argue, the propensity to pay dividends is higher among larger, more profitable companies whose retained earnings account for a large part of the value of their property. Similar reasoning appears in earlier comparative studies (Baker et al., 2007).

Table 1 presents the structure of the respondents by their position in the firms. The data analysis indicates that $68 \%$ of the respondents are directly involved in dividend policymaking, including 63\% representing companies' management. While not directly involved in dividend decision-making, over $32 \%$ of the respondents must be knowledgeable about their companies' dividend policy in order to communicate with shareholders.

\section{Statistical tests}

To test the first hypothesis, the author calculated the arithmetic mean $(\bar{x})$ and standard deviation $\left(\mathrm{s}_{\mathrm{d}}\right)$ of each of the 26 factors influencing the companies' dividend policy. The author used a t-test for the null hypothesis that the mean response for each of the 26 factors influencing dividend policy equals 0 (no importance). For each factor, the author verified the null hypothesis by testing for the absence of significant differences between the arithmetic mean and the value of 2.0 (average weight of the 5 -point scale). This comparison indicates whether the factor is relatively less or more important than the validity referred to as "average". 

Table 2. Ranking of factors influencing dividend policy in selected countries

\begin{tabular}{|c|c|c|c|c|c|c|c|}
\hline \multicolumn{2}{|c|}{ Factor } & \multirow[t]{2}{*}{$\begin{array}{l}\text { Mean of the } \\
\text { sample }(\bar{x})\end{array}$} & \multicolumn{5}{|c|}{ Rank } \\
\hline & & & $\begin{array}{l}\text { Poland } \\
\text { WSE }\end{array}$ & $\begin{array}{l}\text { Norway } \\
\text { OSE }\end{array}$ & $\begin{array}{l}\text { USA } \\
\text { NYSE }\end{array}$ & $\begin{array}{c}\text { USA } \\
\text { NASDAQ }\end{array}$ & $\begin{array}{l}\text { Canada } \\
\text { TSX }\end{array}$ \\
\hline F3 & Level of current earnings & 3.27 & 1 & 1 & 1 & 3 & 4 \\
\hline $\mathrm{F} 1$ & Stability of earnings & 3.11 & 2 & 2 & 5 & 2 & 2 \\
\hline F4 & Level of expected future earnings & 2.98 & 3 & 4,5 & $1^{*}$ & 4 & 1 \\
\hline F21 & Availability of effective investment incentives & 2.80 & 4 & 8,5 & 6 & 15 & 11 \\
\hline F11 & Liquidity constraints, such as the availability of cash & 2.63 & 5 & 4,5 & 7 & 14 & 5 \\
\hline F7 & Availability of alternative sources of capital & 2.50 & 6 & 10 & - & 17 & 15 \\
\hline F6 & Current degree of financial leverage & 2.49 & 7,5 & 3 & - & 10 & 8 \\
\hline F10 & Projections about the future state of the economy & 2.49 & 7,5 & 15,5 & 17 & 18 & 17 \\
\hline F8 & Expected rate of return on the firm's assets & 2.46 & 9 & 7 & 12 & 11 & 10 \\
\hline F26 & $\begin{array}{l}\text { Shareholders' preferences with regard to receiving } \\
\text { dividends on a regular basis }\end{array}$ & 2.41 & 10 & - & - & - & - \\
\hline F13 & $\begin{array}{l}\text { Desire to pay out, in the long run, a given fraction of } \\
\text { earnings }\end{array}$ & 2.40 & 11 & 15,5 & 8 & 7 & 6 \\
\hline F9 & Desire to maintain a target capital structure & 2.33 & 12 & 8,5 & 10 & 6 & 13 \\
\hline F5 & Concerns about affecting the stock price & 2.24 & 13 & 14 & 3 & 5 & 7 \\
\hline F20 & $\begin{array}{l}\text { Financing considerations such as cost of raising funds } \\
\text { externally (debt and equity financing) }\end{array}$ & 2.23 & 14 & 12 & 11 & 19 & 14 \\
\hline F2 & Pattern of past dividends & 2.20 & 15 & 11 & 2 & 1 & 3 \\
\hline F15 & $\begin{array}{l}\text { Existing shareholders' needs, such as the desire for current } \\
\text { income }\end{array}$ & 2.20 & 16 & 21 & 9 & 9 & 9 \\
\hline F25 & $\begin{array}{l}\text { Shareholder structure (State Treasury, investment funds, } \\
\text { companies, individual investors) }\end{array}$ & 1.94 & 17 & - & - & - & - \\
\hline F18 & $\begin{array}{l}\text { Concerns that a dividend change may provide a false } \\
\text { signal to investors }\end{array}$ & 1.74 & 18 & 18 & 4 & 8 & 12 \\
\hline F22 & $\begin{array}{l}\text { Signaling incentives such as using dividend changes to } \\
\text { convey information to the financial markets }\end{array}$ & 1.65 & 19 & 13 & - & 16 & 16 \\
\hline F19 & $\begin{array}{l}\text { Legal rules and constraints such as paying dividends that } \\
\text { would impair the capital structure }\end{array}$ & 1.61 & 20 & 6 & 15 & 12 & 19 \\
\hline F17 & $\begin{array}{l}\text { Preference for paying dividends instead of making risky } \\
\text { investments }\end{array}$ & 1.51 & 21 & 20 & 18 & 20 & 21 \\
\hline F16 & $\begin{array}{l}\text { Contractual constraints, such as dividend restrictions in } \\
\text { debt contracts }\end{array}$ & 1.46 & 22 & 19 & 14 & 21 & 20 \\
\hline F24 & Tax rates on dividends and capital gains & 1.36 & 23 & - & - & - & - \\
\hline F12 & Desire to conform to the industry's payout ratio & 1.30 & 24 & 17 & 13 & 13 & 18 \\
\hline F23 & $\begin{array}{l}\text { Stockholder characteristics, such as marginal tax rates of } \\
\text { company's current shareholders }\end{array}$ & 1.23 & 25 & - & 16 & 22 & 22 \\
\hline F14 & $\begin{array}{l}\text { Desire to conform to the dividend payout ratio of the } \\
\text { market as a whole }\end{array}$ & 1.12 & 26 & 22 & - & - & - \\
\hline
\end{tabular}

Notes: Adapted from author's own calculations based on the WSE survey and Determinants of corporate dividend policy: a survey of NYSE firms, Financial Practice and Education, 10(1), 29-40 by Baker, Powell (2000); The perception of dividends by Canadian managers: new survey evidence, International Journal of Managerial Finance, 3(1), 70-91 by Baker et al. (2001); How Norwegian Managers View Dividend Policy, Global Finance Journal, 17(1), 155-175 by Baker et al. (2005); and The perception of dividends by Canadian managers: new survey evidence, International Journal of Managerial Finance, 3(1), 70-91 by Baker et al. (2007).

*- in the NYSE study, F3 and F1 were merged and became the level of current and expected earnings. 
Norwegian managers rank the current level of financial leverage (F6) third, while in Poland, this factor is ranked seventh. Its high ranking in Norway implies that the respondents are aware that their company's dividend policy is affected not only by the amount of funds available for distribution to shareholders but also by the company's capital structure.

In Canada, the three most important factors are the level of expected future earnings (F4), the stability of earnings (F1) and dividend payouts in previous years (F2). In Poland, the last factor was considered to be of average importance (insignificant difference between the arithmetic mean and the value of 2.0) and was ranked fifteenth place, compared to eleventh for the OSE. The weight that managers attach to future earnings is rational because this factor is strongly connected with cash flow, which is the source of dividend payouts. On the other hand, Poland's top-ranked factor, the level of current earnings (F3), ranks fourth in Canada, and the availability of efficient investment projects ranks eleventh. These results suggest, therefore, that Canadian managers attach more weight than their Polish counterparts to what happened and what will happen to the company's earnings beyond the current performance. An equally important role is played by past dividend patterns, thus confirming that, just as in the USA, Canadian managers highly value continuity and stability of dividend payouts. The low ranking of possible investments as a determinant of dividend policy, coupled with the high weighting of past dividend patterns, provides evidence that Canadian companies are more inclined to follow a predetermined payout policy than to apply a residual policy.

The same conclusion holds for the US stock exchanges. Past dividend payouts are in fact the most important determinant for NASDAQ managers and the second most important determinant for NYSE managers. The perception of this particular determinant seems to mark one of the most important differences between the Polish and Norwegian rankings and the Canadian and American rankings. A conclusion can be drawn from the above that TSX, NASDAQ and NYSE managers make decisions based on the Lintner model more than their Polish colleagues. One should also note that companies operating in these mature markets developed dividend models in past periods, which indicates that the maturity of the capital market also affects firms' dividend policy.

The next two factors, the availability of effective investment incentives (F21) and liquidity constraints (F11), are ranked fourth and fifth on the WSE, while on the Oslo and NYSE stock exchanges, these factors are among the top ten antecedents, although they are relegated to rankings between tenth and twentieth on the remaining two stock exchanges. Liquidity constraints such as the availability of cash (F11) is the fifth most frequently quoted determinant of dividend policy for Polish, Norwegian and Canadian companies. Managers from these three markets exhibit notable coherence in their attitudes. They are aware that companies pay dividends out of existing cash rather than from earnings derived through accrual accounting, and, therefore, it is cash availability that affects a company's ability to pay cash dividends. NYSE managers rank liquidity constraints (F11) as the seventh (out of 22) most important determinant of dividend payouts. In contrast, the perception of these factors (F21, F11) by managers of NASDAQ-listed companies indicates considerable differences of opinion. Liquidity is ranked only as the fourteenth most important factor out of the total of twenty-two factors, and the availability of effective investment incentives, which the Polish market sees as the fourth most important factor, is ranked fifteenth. It is also worth noting evidence of differences of opinion with respect to the last issue among managers of TSX-listed companies, where possible investment incentives are ranked only eleventh.

The availability of alternative sources of capital (F7), which ranks sixth in the Polish survey, occupies a lower place in Norway (10th out of 22). F7 is also considered to be a low weight factor in Canada (15th out of 22) and on the NASDAQ, where it is merely seventeenth (out of 22). This result attests to the fact that Polish managers experience greater difficulty in finding sources of financing than their colleagues in the countries used for comparison, as Polish companies have limited access to the debt market. The Catalyst bond market is still underdeveloped. In the debt structure, bonds account for merely $12 \%$ of the total debt, while $88 \%$ of the debt comes from loans, which are difficult to obtain in an economic downturn. In addition, Poland's interest rates have been much higher than those in other EU countries for the last dozen 
years. On average, bonds account for $20 \%$ of the total corporate debt in the EU, compared to $80 \%$ in the US, with loans accounting for only $20 \%$ of the total debt (Gałka 2015).

Similarly, predictions of the future health of the economy are treated in Poland as a priority (7th most important out of 26), but less so in Norway (16th out of 22 ), the USA (NYSE), Canada (17th out of 22) and for NASDAQ-listed firms (18th out of 22). The expected return on assets is of the most importance for Norwegian managers (7th out of 22). In Poland, this determinant ranks ninth, in Canada tenth, eleventh on the NASDAQ and twelfth on the NYSE.

From the point of view of the US markets, the impact of dividends on a company's share price is quite an important factor in firms' dividend policy. Both firms listed on the NYSE and the NASDAQ rank it among the five most important factors. An increase in the company's market value is frequently one of the measures adopted to determine the bonuses of US managers. However, this factor has much less importance for Polish managers, falling outside the top ten factors (13th out of 26), and likewise for Norwegian firms (14th out of 22).

The needs of current shareholders, for example, a desire to acquire current earnings (F15) (9th out of 22), are considered more seriously in the US and Canada than in Poland, where such concerns rank sixteenth. Norwegian managers rank this factor only 21 st.

The comparison reveals a difference in managers' approach to the avoidance of false signals to investors by changing the amount of their dividend payouts (F18). NYSE managers rank this factor fourth, that is, as a very important factor in the hierarchy. This result means that the signaling effect, despite affirmation by managers from all four countries of their support for the underlying theory, gains actual recognition only on the New York stock exchange. Respondents from the NASDAQ ranked this factor (F18) eighth and Canadian respondents twelfth. Factor (F18) is afforded the least attention by Polish and Norwegian managers, who rank it eighteenth. In Norway, managers' moderate level of concern about sending a false signal about the condition of the company is probably due to the existence of specific regulations and government control. Norwegian companies experience fewer agency problems than their US counterparts due to a concentrated ownership structure and the large Treasury ownership of listed companies. In Poland, shareholder protections have recently been strengthened with the introduction of class action lawsuits against companies.

Norwegian managers' approach to regulations and legal restrictions on the payment of dividends (e.g., equity depletion) also differs. This factor is ranked sixth in Norway, compared to its much lower ranking by Polish companies (20th out of 26), and its rank of fifteenth on the NYSE, nineteenth on the TSX and twelfth on the NASDAQ. The difference stems from regulatory differences between the countries. As mentioned previously, Norway's centralized government (Baker et al. 2006) has established very strict regulatory standards that exert a strong influence on the business environment in order to afford shareholders broad legal protection.

The least important factors from the perspective of all the surveyed groups are investor characteristics such as marginal tax rates and adjustments to the dividend rate across the market. These factors are ranked at the bottom of all the rankings. Tax issues are therefore not considered significant by the managers.

The calculation of Spearman's rank correlation coefficients (rs) allows a determination of the strength of the links between the Polish hierarchy of antecedents with those identified from research in other countries. The author obtained statistically significant results of $\mathrm{rs}+0.732$ for the comparison between the WSE and the OSE, +0.450 for the comparison between the WSE and the NYSE, +0.516 for the comparison between the WSE and the NASDAQ and +0.707 for the comparison between the WSE and the TSX. These high correlation coefficients generally show that Polish, Norwegian, Canadian and American managers build their rankings of factors affecting firms' dividend policy in much the same way, despite the different characteristics of the companies and the markets in which they operate.

\section{Summary and conclusions}

To summarize the discussion of the hierarchy of factors shaping the dividend policy for firms in Poland, the USA, Canada and Norway, one first observes that this hierarchy does not differ significantly. The most important antecedents of dividend policy for compa- 

Gałka, T. (2015). Ewolucja rynku obligacji korporacyjnych $w$ Polsce [Evolution of corporate bonds market in Poland]. Retrieved from http:// www.case-research.eu/sites/default/files/T. Ga\%C5\%82ka_prezentacja.pdf

Kowalewski, O., Stetsyuk, I., \& Talavera, O. (2007). Corporate governance and dividend policy in Poland (Discussion Paper No. 702). DIW Berlin, German Institute for Economic Research.

Kowerski, M. (2010). Wpływ nastrojów gospodarczych przedsiębiorców i konsumentów na decyzje dywidendowe spółek kapitałowych [The influence of the economic sentiment of enterpreneurs and consumers on corporate dividend decisions], Barometr Regionalny, 2(20), 19-34.

Lintner, J. (1956), Distribution of incomes of corporations among dividends, retained earnings and taxes. American Economics Review, 46(2), 97-113.

Sierpińska-Sawicz, A. (2014). Dividend policy of State Treasury Shareholding Companies. Journal of Economics and Management, Katowice, 18, 225-241.

Warsaw Stock Exchange (2015a). WSE Fact Books 2002-2013, 2015, Available from www.gpw.pl

Warsaw Stock Exchange (2015b). Udział inwestorów $w$ obrotach instrumentami finansowymi na $G P W$ [ Investors share in financial instruments trade at WSE], Available from www.gpw.pl/ wydarzenia/?ph_tresc_glowna_start=show\&ph_ tresc_glowna_cmn_id $=57483$ 